\title{
Research on Social Responsibility of the Accounting Firms Under the Dig Data Environment
}

\author{
Xien Li \\ \#16, South Section, 1st Ring Road, Southwest University for Nationalities,Chengdu, Sichuan, China \\ 511169896@qq.com
}

Keywords: Big data ;Certified public accountants; Social responsibility

Abstract: In the time of big data,the connotation of the social responsibility of enterprises is to be extended, showing new characteristics, and at the same time, the mode of disclosure will also produce a new evolutionary. As a special form of enterprise,Certified public accountants'social responsibility will be redefined. This paper aims to analyze the content of social responsibility of accounting firms in our country under the environment of big data, and puts forward appropriate recommendations to ensure accounting firms fulfilling their social responsibilities in a better way.

\section{Introduction}

Since the American scholar Sheldon put forward the concept of "corporate social responsibility"(CSR) in 1924, the study of social responsibility can never stop. Now social responsibility has developed into a comprehensive problem covering economics, laws, politicalscience, management ,sociology and other academic areas. However, researches on social responsibility of accounting firms started relatively late. LuDaifu (2008), the earlier researcher studied on social responsibility, believes that social responsibility is the basis of accounting firms long-term development; Liu Yuting (2010)compared undertaking the social responsibility with complying with accounting standards, providing a high qualified financial reporting in the equally important position. Researches on social responsibility of accounting firms abroad mainly include Johnson (1971), he believes that the interests of the enterprise is divided into short-term and long-term interests, and to realize its long-term interests ,social responsibility will play a crucial role;M.Porter's(2006) view is that social responsibility of enterprises brings competitive advantages, fulfilling the social responsibility actively will exert positive effects on the reputation of the enterprise and create value for the enterprise; Donald and Martin (2012) pointed out that, nowadays most enterprises committed to establish a good image of fulfilling social responsibility .In November 2010, the international organization for standardization has officially released the first international standard ISO260000 about social responsibility. This means the formation of international Guidance document on supervision and management of fulfilling social responsibility .

In recent years,"Era of Big Data” has been frequently mentioned . It has broken down the barriers between market and industry, brought new opportunities and challenges to enterprises and even the society.Under the strong impact, the content and the way in which accounting firms fulfill their social responsibilities is bound to change.

\section{The meaning of public accounting firm to undertake social responsibility in our country}

Certified public accountants plays an irreplaceable role in the development of capital market For a long time.The users of financial reports can't ignore the supervision and disclosure implemented by Certified public accountants. However, in recent years, financial fraud and audit failure scandals at home or abroad occurred one after another. As a result, auditor's quality and professional ethics are doubted by the public, the meaning of the accounting firms to undertake social responsibility is more important.

2.1It is conducive to the accounting firm's long-term development. Honesty is the cornerstone of the accounting firms to conduct business, especially when the CPA conducts audit work.Performing t social responsibility is of great significance to brand building and image shaping of accounting firms.Good performance will shape a good brand image, draw empathy and trust of 
the public, eventually it will be transformedinto loyalty to the brand.

2.2 It will promote the development of accounting industry.Firms' bearing of social responsibility actively is conducive to enhancing the image of the industry, establishing the trust industry, and providing guarantee for the existence of the industry improvement.Due to the particularity ofAudit services, it's hard for the public to understand its functioning.Through a positive commitment to social responsibility, firms will have a chance to show their good social image,improve the quality of the business, build a good reputation. As a result ,the accounting industry will be better developed by leaps and bounds.

2.3 It is going to contribute to the healthy development of capital market. Accounting firms take part in the competition of market as a role of third party. Its main function is to carry out the audit business and issue the audit report. Based on the principal-agent theory, certified public accountants use their own professional knowledge to evaluate achievement of operator's operation and management,and then report to the owner. The realization of this function is based on the firm's professional competence and independence. If, on the other hand, the registered accountant lack the independence or professional judgment in the process of audit, investors will make wrong judgment based on the feedback information, suffer huge losses, resulting in confusion and panic in the capital market.

2.4 It will arise the public attention on social responsibility. Due to its particularity,certified public accountants stand in a coastal area between enterprises, government and individuals. Accounting firms conduct business by verification and audition, so its connection to the enterprise is inseparable. Firms fulfill their social responsibilities actively, and through this link they participate in the economic activities of the parties, so that social responsibility can be taken seriously, and be practiced.

\section{The content of the accounting firms social responsibility in our country}

As to the content of the social responsibility, experts and scholars at home and abroad has given different connotations according to different criteria. This article will refer to Carol's social responsibility pyramid model, combined with the actual situation of our country, define the content of the accounting firms social responsibility. According to Carol's social responsibility pyramid model, the social responsibility of the enterprise can be summed up as economic responsibility, legal responsibility, ethical responsibility and philanthropic responsibility.

\subsection{Economic responsibilities}

3.1.1Reflect the enterprise's financial position and operating results truthfully, provide real and effective financial information, issue reliable audit report on its independence and professional judgment, be responsible for report users, protect the legitimate rights and interests of investors, which is the accounting firms' most basic social responsibility.

3.1.2Improve the operational capacity, enhance the professional quality, adhere to the principle of independence, and make the audit opinion objectively and fairly according to the audited financial report . At the same time, they are required to keep business secrets, perfect service system, and ensure the quality of service.

3.1.3Accounting firms should also protect the rights of employees, provide a comfortable working environment for employees, provide training programs and education services.

3.1.4Accounting firms' performing of economic responsibility is also reflected in the setting of business. At present, "climate change and sustainable development has become the new business of accounting firms, specific content includes review of climate change, climate change strategy evaluation and implementation, low-carbon supply chain management.

\subsection{Legal responsibilities}

3.2.1 Maintain independence. Independence is regarded as the soul of the audit business. Lost the independence of audit is the equivalent of the audit failure.

3.2.2 Certified public accountants function as a carrier of the certified public accountants to carry out audit business, its independent objective stance is of great significance to CPA's independence. 
3.2.3Provide professional help for legal investigation.With a large number of accounting, taxation, asset appraisal, management control talents, when it comes to cases that involved in financial fraud and tax evasion, accounting firms can provide professional means to find out the truth, cooperating with the investigation. Forensic accounting personnel in accounting firms can also collect information through their professional skills, protect consumers' legitimate rights and interests.

3.2.4 Pay taxes on time and in full amount.Certified public accountants pay taxes on time and in full amount reflects the contribution to the social development, support for building a well-off society in an all-round way, it also reflects the firm's own professional quality.

\subsection{Ethical responsibilities}

3.3.1Keep healthy competition relationship with other accounting firms.This is also the requirement of certified public accountant professional ethics in our country. Firms compete with each other fairly, not in the form of malicious reduction, or by reducing the quality of service .Only in this way ,the capital market can maintain a stable development, and the whole industry will function in order.

3.3.2 Public welfare donations and public welfare funds. Certified public accountants can fulfill social responsibility by charitable donations and public funds. They can provide professional services for non-profit organization, carry out various cultural activities and cooperate with the press, advertising firm's business philosophy, service characteristics to set up a good public image.

3.3.3The accounting firm can fulfill its environmental responsibility by saving resources, lowering carbon emissions, purchasing low carbon environmental protection materials and so on.

\section{4 the social responsibility of accounting firms in the big data environment}

4.1Big data era. Big data, refers to the data collection can’t be captured ,managed or dealt with by conventional software tools within the affordable time. McKinsey global institute (MGI) (2011) give the definition of "big data" as: a large scale of acquisition, storage, management, analysis, beyond the traditional scope of data collection, it shares characters as a variety of data types, value of low density.He also pointed out: "data has penetrated every industry and business functional areas, gradually become an important production factor."

\subsection{New characteristics of accounting firm's social responsibility under the big data} environment

4.2.1Comprehensive. Based on large data environment, certified public accountants can obtain all the management information of the enterprises. Pieces of information will be converged into a complete business process .So each individual business behavior will profoundly influence its sustainable development.

4.2.2 Accuracy.Calculation of cloud data with large data avoid the omission and one-sided results, the firm's history information has been covered uptake. By this calculation, we get the results more precise, the supervision of accounting firms can be more effective.

4.2.3Initiative. Firm's business activities can be recorded by financial data, as to its social responsibility, however, there is no corresponding "evidence". Therefore, although firms have promptly undertook social responsibility, the public have no idea of that.Large data environment provide the possibility for that, each practice of performance will be recorded in the cloud, and access to the message of the audience also has a substantial increase.

\section{Conclusions-How accounting firm perform social responsibility under the environment of big data}

\subsection{From their own aspect}

5.1.1Comply with the environmental changes, realize that big data age has come,they must adapt to the environment change.The social responsibility is now on a more important strategic position,sothey must improve the consciousness of social responsibility and execution, 
5.1.2Strengthen self construction, improve the quality of personnel.Use the database to get a comprehensive grasp of the staff's quality as well as to strengthen the business training, improving their professional competence, emphasizing the importance of independence.

5.1.3Conduct strategic management,win the competition advantage.Conclude social responsibility into the firm's development strategy system, fulfill the social responsibility in a planned ,systematically and stably way.

\subsection{From external aspect}

5.2.1Establish the integrity of the database and strengthen regulatory constraints. The integrity of the accounting firms and certified public accountants database can truly reflect the practice situation, also can truthfully reflect how the firm fulfill their social responsibility. Transfer social responsibility from moral restraint into legal norms, ensure accounting firms to fulfill their social responsibility.

5.2.2Promote industry self-regulation, establish a unified system. Unified social responsibility auditing standards system is conducive to regulating the industry and competition. Promote external environment, at the same time form a complete set of internal unity, which will certainly promote accounting firms to perform the social responsibility and strengthen its motivation.

\section{References}

[1]Lu Daifu.2002.Economics and law analysis on Corporatation social responsibility of [M]. Beijing: law press.

[2]ShenYi,XuGuanghua,Wang Zhengyan.2014."consistency"of the corporate social responsibility information disclosure framework, the evolution of the big data environment. Accounting research [J], 9:29 36.

[3] Donald,V.M.,P.R.Martin.2012.A Broader Perspective on Corporate Social Responsibility Research in Accounting[J].The Accounting Review,87 (3) : $797 \sim 806$.

[4]Li Yuan. 2014.Research on Public accounting firms’ social responsibility [D].Zhejiang, Zhejiang university of finance and economics.

[5]Michael Porter. 2003. Competition theory [M]. Citic publishing house.

[6]Jeremy Rifkin. 2012. The third industrial revolution [M]. Citic publishing house. 